\title{
Scanning Electron Microscopic study of Piper betle L. leaves extract effect against Streptococcus mutans ATCC 25175
}

\author{
Zubaidah Haji Abdul RAHIM', Nalina THURAIRAJAH²
}

1- BSc Hons, PhD, Department of Oral Biology, Dental School, University of Malaya, Kuala Lumpur, Malaysia.

2- BSc Hons, MSc, PhD, UCSI University, Dental School, University of Malaya, Kuala Lumpur, Malaysia.

Corresponding address: Zubaidah Hj Abd Rahim (PhD) - Department of Oral Biology, Faculty of Dentistry - University of Malaya, 50603 - Kuala Lumpur Malaysia - Phone: 603-79674851 - Fax: 603-79674536 - e-mail address: zubaidar@um.edu.my

Received: June 16, 2009 - Modification: November 24, 2009 - Accepted: March 19, 2010

\section{ABSTRACT}

Tntroduction: Previous studies have shown that Piper betle L. leaves extract inhibits 1 the adherence of Streptococcus mutans to glass surface, suggesting its potential role in controlling dental plaque development. Objectives: In this study, the effect of the Piper betle L. extract towards S. mutans (with/without sucrose) using scanning electron microscopy (SEM) and on partially purified cell-associated glucosyltransferase activity were determined. Material and Methods: S. mutans were allowed to adhere to glass beads suspended in 6 different Brain Heart Infusion broths [without sucrose; with sucrose; without sucrose containing the extract ( $2 \mathrm{mg} \mathrm{mL}^{-1}$ and $\left.4 \mathrm{mg} \mathrm{mL}^{-1}\right)$; with sucrose containing the extract ( $2 \mathrm{mg} \mathrm{mL}^{-1}$ and $4 \mathrm{mg} \mathrm{mL}^{-1}$ )]. Positive control was $0.12 \%$ chlorhexidine. The glass beads were later processed for SEM viewing. Cell surface area and appearance and, cell population of $S$. mutans adhering to the glass beads were determined upon viewing using the SEM. The glucosyltransferase activity (with/without extract) was also determined. One- and two-way ANOVA were used accordingly. Results: It was found that sucrose increased adherence and cell surface area of $S$. mutans $(p<0.001)$. S. mutans adhering to $100 \mu \mathrm{m}^{2}$ glass surfaces (with/without sucrose) exhibited reduced cell surface area, fluffy extracellular appearance and cell population in the presence of the Piper bet/e L. leaves extract. It was also found that the extract inhibited glucosyltransferase activity and its inhibition at $2.5 \mathrm{mg} \mathrm{mL}^{-1}$ corresponded to that of $0.12 \%$ chlorhexidine. At $4 \mathrm{mg} \mathrm{mL}^{-1}$ of the extract, the glucosyltransferase activity was undetectable and despite that, bacterial cells still demonstrated adherence capacity. Conclusion: The SEM analysis confirmed the inhibitory effects of the Piper bet/e $L$. leaves extract towards cell adherence, cell growth and extracellular polysaccharide formation of $S$. mutans visually. In bacterial cell adherence, other factors besides glucosyltransferase are involved.

Key words: Bacterial adhesion. Glucosyltransferases. Streptococcus mutans. Scanning electron microscope.

\section{INTRODUCTION}

Plants belonging to the genus Piper are reputed in the Indian Ayurvedic system of medicine for their medicinal properties ${ }^{9,31}$ and in folklore medicine of Latin America and West Indies. Piper betle L. (Piperaceae) leaves have a strong pungent aromatic flavour. In medicine, the leaves are useful in catarrhal and pulmonary infections ${ }^{31}$. The practice in India is to chew the leaves alone or with areca nut and other spices such as cardamom, clove and cinnamon, which act as "breath fresheners" and help in the prevention of halitosis. The phenolic constituent, allylpyrocatechol from the leaves showed activity against obligate oral anaerobes responsible for halitosis ${ }^{22}$. It has also been reported that the crude aqueous extract of Piper betle inhibits growth ${ }^{5}$ and adherence of early plaque settlers, which include S. mitis, S. sanguinis and Actinomyces $s p$. to saliva-coated glass surfaces ${ }^{23}$. 
Other plant extracts like that of Syzygium aromaticum ${ }^{21}$, Polygonum cuspidatum ${ }^{27}$, Andrographis paniculata, Cassia alata, Chinese black tea, Guava, Harrisonia perforata ${ }^{10}$, Propolis Type $6^{3}$ and cacao bean ${ }^{18}$ also have an antiadherence effect. The adhering property could contribute to the virulence activity of the bacteria ${ }^{11,12}$. The ability to adhere to oral surfaces so successfully is one of the factors that afford these bacteria a critical role in the formation of dental plaque which, eventually lead to oral diseases such as caries, gingivitis and periodontitis ${ }^{1,13,15}$. In previous studies, it has been reported that the crude aqueous extract of Piper betle $\mathrm{L}$. leaves exhibit antivirulence and antibacterial activities towards $S$. mutans ${ }^{16}$. It was suggested that the antimicrobial activity is attributed to the hydroxychavicol component of the extract ${ }^{25}$.

Streptococcus mutans has been implicated as one of the primary causative agents of dental caries in human and experimental animals ${ }^{6,19}$. The bacteria after the initial colonization of the pellicle will attach strongly to the tooth surface by the extracellular polysaccharides (EPS). These extracellular polysaccharides are synthesized by the S. mutans in the presence of sucrose via the enzymatic action of one or more glucosyltransferases (GTFs). GTF activity may represent the virulence factor of mutans Streptococci and can be used as an index for determining the antivirulence activity of the extract. The presence of GTF-isoforms B, C and $D$ as seen under electron microscopy within all layers of the in situ formed pellicle ${ }^{7}$ may affirm their significant role in plaque development. The results obtained from previous work ${ }^{17}$ have indicated the Piper betle L. extract affects the adhering capacity of $S$. mutans via inhibition of the GTF activity and hence the extracellular polysaccharide formation. This conclusion was based on biochemical and microbiological studies. The objectives of this study were to use scanning electron microscopy (SEM) to demonstrate visually the effect of the aqueous extract of Piper betle L. leaves in the presence and absence of sucrose on the cell adherence, cell growth and extracellular polysaccharide formation of $S$. mutans and to relate the effect of the extract on the GTF activity with bacterial adherence.

\section{MATERIAL AND METHODS}

\section{Preparation of crude aqueous extract of the leaves of Piper betle \\ The leaves of Piper betle L. were obtained from one source in Mentakab, Pahang. Crude aqueous extract of the leaves was prepared according to Nalina and Rahim ${ }^{17}$ (2006). Before use the dried pellets were weighed, dissolved and diluted to the required concentrations using deionized distilled water. This is followed by filtration using $0.2 \mu \mathrm{m}$}

nylon syringe filters (Milipore, Billerica, MA, USA) which is for sterilization process ${ }^{26}$.

\section{Preparation of bacterial suspension}

Streptococcus mutans ATCC 25175 [American Type Culture Collection (ATCC), Manassas, VA 201808, USA] suspension was prepared according to Nalina and Rahim ${ }^{17}$ (2006). The bacterial stock which was kept frozen in glycerol at $-70^{\circ} \mathrm{C}$ before use was thawed at room temperature to revive the bacteria. The thawed stock was then dispersed in $30 \mathrm{~mL}$ Brain Heart Infusion (BHI) broth (Oxoid, Hampshire, England) before incubating it at $37^{\circ} \mathrm{C}$ for 18-20 h. The number of bacterial cells in the suspension used in the study was standardized by adjusting the absorbance of the bacterial suspension spectrophotometrically $\left(\mathrm{OD}_{550 \mathrm{~nm}}\right)$ to 0.144 . This absorbance is equivalent to $10^{6}$ cells $\mathrm{mL}^{-1}{ }^{23}$. To ensure that only pure culture of the stock are used in the study, the revived bacteria were consistently tested for purity by culturing them on BHI plates containing $5 \%$ blood.

\section{SEM analysis on the adherence capacity and growth of S. mutans}

SEM analysis was done to determine a) the effect of sucrose on the growth and adherence capacity of $S$. mutans to glass surface and b) the effect of Piper betle L. leaves extract on the adherence capacity and growth of $S$. mutans on the glass surface in the presence and absence of sucrose. The adherence capacity was determined from the bacterial cell population adhering to the surface of glass beads and the growth from the size and dividing appearance of the bacterial cells. The extracellular surface appearance of bacterial cells as viewed by SEM was also noted.

a) Effect of sucrose on the growth and adherence capacity of $S$. mutans to glass surface

The assay was based on a modification of the method developed by Ooshima, et al. ${ }^{18}$ (2000). $3 \mathrm{~mL}$ of Brain Heart Infusion (BHI) broth (Oxoid) containing $1 \%(\mathrm{w} / \mathrm{v})$ sucrose $(\mathrm{BDH})$ was pipetted into a vial containing sterile glass beads (diameter: $3 \mathrm{~mm}$ ) (Merck, Darmstadt, Germany). This was followed by the addition of bacterial cell suspension containing S. mutans (equivalent to $\times 10^{6}$ cells $\mathrm{mL}^{-}$ ${ }^{1}$ ). The mixture was then incubated at $37^{\circ} \mathrm{C}$ in an inclined position at an angle of 30 degrees for $18 \mathrm{~h}$. This time duration allows the bacterial cells to be in the stationary phase. After the $18 \mathrm{~h}$ incubation, the glass beads were then washed with sterile deionized water and transferred into $1 \mathrm{~mL}$ of glutaraldehyde (Sigma Aldrich Co., St. Louis, MO, USA) (4\%) to fix the cells and left overnight at $4^{\circ} \mathrm{C}$ for the SEM analysis. SEM was used to view and record the cell 
population, cell growth and extracellular surface appearance of $S$. mutans. The assay was carried out in triplicate.

For blank control, the assay was repeated using $\mathrm{BHI}$ without bacterial inoculation. The blank control was to validate that the assay is devoid of bacterial contamination. For negative control, the experiment was repeated using $\mathrm{BHI}$ broth without sucrose.

b) Effect of Piper betle L. leaves extract on the adherence capacity and growth of $S$. mutans on the glass surface in the i) absence and ii) presence of $1 \%$ sucrose

The assay procedure in a) was repeated with the addition of the Piper betle extract at the respective concentrations ( $2 \mathrm{mg} . \mathrm{mL}^{-1}$ and $4 \mathrm{mg} . \mathrm{mL}^{-1}$ ) to the inoculated $\mathrm{BHI}$ broth. In the determination of $\mathrm{i}$ ) the effect of plant extract in the absence of sucrose, the BHI broth devoid of sucrose was used and (ii) the effect of plant extract in the presence of sucrose, the BHI broth containing $1 \%$ sucrose was used.

Sterile deionized distilled water and $0.12 \%$ chlorhexidine were used in place of the plant extract for negative and positive controls respectively and the assays were also carried out using the BHI broth with or without sucrose. The beads from the experiments were also processed for the SEM study. All of the above assays were carried out in triplicates. There were 9 beads to be viewed under SEM for each experiment with the respective broths.

\section{Preparation of the glass beads for SEM analysis}

The glass beads that had been fixed overnight in glutaraldehyde were then processed for SEM analysis according to the following steps. First, the glass beads were washed with sodium cacodylate (Sigma Aldrich Co.) buffer (0.1 M at pH 7.4) and then fixed in $2 \%(\mathrm{w} / \mathrm{v})$ osmium tetroxide (Merck) in the buffer solution overnight. The next day, the beads were gently washed in distilled water twice for 15 min and then dehydrated in an ascending series of ethanol (BDH Laboratories Supplies; VWR International, Lutterworth, Leicestershire, UK) concentrations $(10,20,30,40,50,60,70,80,90$ and 95\%) for
15 min for each step. Following this, the beads were further dehydrated in $100 \%$ ethanol twice for 15 min and subsequently in ethanol:acetone mixture as follows, firstly, ethanol:acetone (3:1) for $15 \mathrm{~min}$, then ethanol:acetone $(1: 1)$ for $15 \mathrm{~min}$ and followed by ethanol:acetone (BDH) (1:3) for $15 \mathrm{~min}$. Finally, the beads were treated 3 times with pure acetone for $15 \mathrm{~min}$.

The beads were then processed for critical point drying for about $2 \mathrm{~h}$. Once the beads were completely dry, they were mounted onto metal stubs with double sided tape and then coated with gold. Three beads from each assay were then used for viewing using a scanning electron microscope (Phillips, Eindhoven, Netherlands).

\section{Determination of the number of bacterial cells adhering to the glass surface}

The number of cells adhering to the glass surface on a $100 \mu \mathrm{m}^{2}$ area of the glass bead viewed at a magnification of 5,000x was calculated and the total number of cells was determined from an area of 1 $\mathrm{mm}^{2}$ of the glass surface. The area with high density of bacteria cells was used in the calculation of the number of cells (Figure 1). In total, 9 beads from 3 different assays per experiment were processed and analyzed.

\section{Determination of bacteria cell surface area}

The beads were viewed at a magnification of $10,000 x$. At this magnification, the size of the cell is magnified and thus measurement is easily done. The size of the individual adhered bacterial cell was measured according its length ( $L$ ) and width $(W)$ in $\mu \mathrm{m}$ and expressed as the mean surface area [ $L \pm S D$ $x \mathrm{~W} \pm \mathrm{SD}$ ] in $\mu \mathrm{m}^{2}$ of the total number of adhered cells from 9 beads used in the determinations.

\section{Determination of the appearance of the extracellular surface}

This was carried out by comparison with the appearance of the extracellular surface of S. mutans adhering to hydroxyapatite beads ${ }^{28}$.

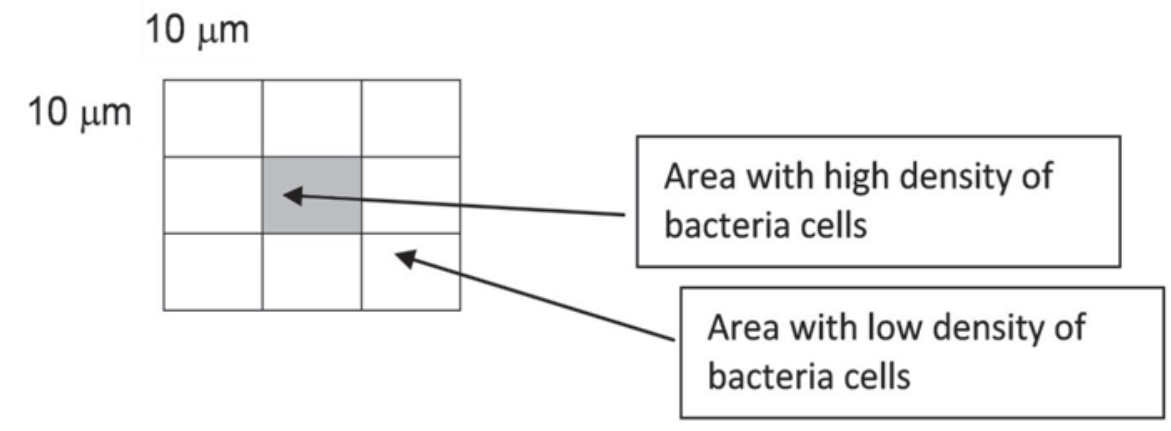

Figure 1- Diagram showing the calculation for the number of bacterial cells on $100 \mu \mathrm{m}^{2}$ area in a total area of $1 \mathrm{~mm} \mathrm{~m}^{2}$ of the glass surface. The area with high density of bacteria cells was used in the calculation of the number of cells in Table 1 
Preparation of partially purified cellassociated GTF of S. mutans

Crude GTF was isolated from S. mutans ATCC 25175 strain in the research laboratory, Oral Biology Department, University of Malaya using the method described by Ooshima, et al. ${ }^{18}$ (2000) with slight modification ${ }^{17,21}$. The crude enzyme was then subjected to partial purification by ultra-filtration (Macrosep Omega membrane - $\mathrm{mw}$ cut off $=300 \mathrm{kd}$; Pall Life Science, Exton, PA, USA). The crude enzyme was then centrifuged using the centrifugal filter (Macrosep Omega membrane; Pall Life Science) at $5,000 \mathrm{~g}$ for $20 \mathrm{~min}$ to remove residual cells and the supernatant collected was then referred as partially purified crude enzyme. The partially purified crude enzyme was kept in the freezer $\left(-20^{\circ} \mathrm{C}\right)$ to be used for further analyses.

Determination the effect of the extract towards partially purified cell-associated GTF (CAG) activities

The reaction mixture used in the determination of the partially purified cell-associated GTF activity was adapted from the method described by Mukasa, et al. ${ }^{14}$ (1979) and modified to suit the experiment carried out in this study. The reaction mixture consists of $0.01 \%$ of thimerosal (Sigma Aldrich Co.), $1.4 \mathrm{~g}$ of sucrose, $34.3 \mathrm{mg}$ of exogenous dextran (ICN Biomedicals, Aurora, OH, USA) and mixed in $100 \mathrm{~mL}$ of $5 \mathrm{mM}$ sodium phosphate (Sigma Chemical Co.) buffer ( $\mathrm{pH} \mathrm{6.5).100} \mathrm{mL} \mathrm{of} \mathrm{the} \mathrm{partially}$ purified cell-associated GTF was pipetted into the reaction mixture to give a final volume of $2 \mathrm{~mL}$. The mixture was then incubated at $37^{\circ} \mathrm{C}$. After 18 $\mathrm{h}$ (to allow the enzyme to catalyze the formation of glucan sufficient for quantification of glucose), the reaction was terminated by placing the tube in a boiling water bath for $5 \mathrm{~min}$. After $5 \mathrm{~min}$, the mixture was centrifuged (Sigma 302K, Osterode, Germany) at $2,000 \mathrm{~g}$ for $10 \mathrm{~min}$. The pellet obtained after centrifugation was collected and used in the determination of water-insoluble (WIS) extracellular polysaccharide content while the supernatant was discarded.

The pellet was washed 3 times each with $5 \mathrm{~mL}$ of distilled water and then uniformly suspended in $1 \mathrm{~mL}$ of distilled water by agitation. $50 \mathrm{~mL}$ of the WIS extracellular polysaccharide suspension was then pipetted into a clean test tube and assayed for glucose content.

The experiment was repeated by adding the plant extract at the respective concentrations $(0-4.0 \mathrm{mg}$ $\mathrm{mL}^{-1}$ ) to the enzyme reaction mixtures. Comparison was made between the activities of partially purified CAG treated with plant extract and that without the treatment. The activity of the enzyme in the presence of $0.12 \%$ chlorhexidine (Sigma Aldrich Co.) was also determined using the same procedure.
Determination of glucose content of the WIS glucan

The determination of glucose was carried out according to the method by Dubois, et al. ${ }^{4}(1956)$. To $50 \mathrm{~mL}$ of the WIS glucan suspension, $50 \mathrm{~mL}$ of deionized distilled water was added and this was followed by the addition of $50 \mathrm{~mL}$ of phenol (Sigma Aldrich Co.) $(80 \% \mathrm{w} / \mathrm{v})$. The mixture was vortexed and subsequently $2 \mathrm{~mL}$ of concentrated sulfuric acid (R\&M Chemicals, Essex, UK) was added to the mixture. This mixture was then allowed to stand for $10 \mathrm{~min}$ at room temperature before its optical density at $490 \mathrm{~nm}$ was measured. For the standards, a range of volumes $(0-100 \mathrm{~mL})$ of the stock glucose (Sigma Aldrich Co.) solution ( $1 \mathrm{mg} \mathrm{mL}^{-}$ ${ }^{1}$ ) was prepared to give a range of final concentration from 0 to $1 \mathrm{mg} \mathrm{mL}^{-1}$. For the blank control, $100 \mathrm{~mL}$ of deionized distilled water was used instead. The determinations were carried out in triplicates.

The glucose content determined corresponds to the amount of extracellular polysaccharide formed by the partially purified GTF within the specific time which was then used in the calculation of the GTF activity. The enzyme activity is expressed as $\mu \mathrm{mol}$ glucose in the extracellular polysaccharide produced per min ( $\mu$ mole glucose $\left.\mathrm{min}^{-1}\right)^{21}$.

\section{Statistical analysis}

Normality tests for all the data obtained were carried out using the Shapiro-Wilks analysis. The data for the comparison of the cell population and cell growth in the respective experiments were analyzed using a two-way ANOVA. For the comparison of the partially purified CAG activities between the different experiments, a one-way ANOVA was used.

\section{RESULTS}

Effect of sucrose on the adherence capacity and growth of $S_{\text {. mutans on glass surface }}$

Figure 2 shows SEM micrographs $(10,000 x$ magnification) for blank control (BHI without bacterial inoculation), negative control (inoculated $\mathrm{BHI}$ without sucrose) and test (inoculated BHI with sucrose) based on SEM viewing at. These images provide qualitative observations of the cell population which was used to determine the adherence capacity of $S$. mutans to glass surface. It was shown that there were no cells adhering to the glass surface in blank control (BHI without bacterial inoculation) (Figure 2A). This indicates that the experimental procedures are assured of the exclusion of bacterial contamination. The number of cells adhering to the glass surface when grown in the absence of sucrose was less (Figure 2B) compared to that in the presence of $1 \%$ sucrose as shown in Figure $2 \mathrm{C}$. It was observed more cells were adhering 


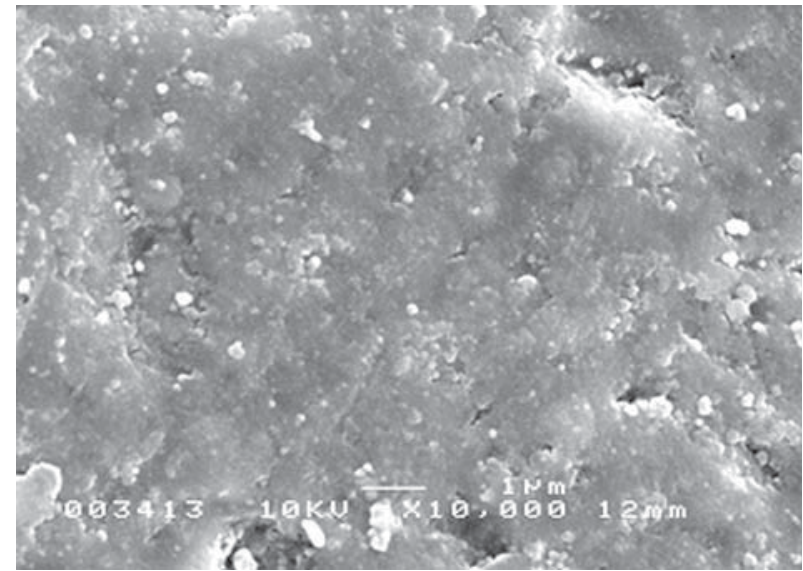

A

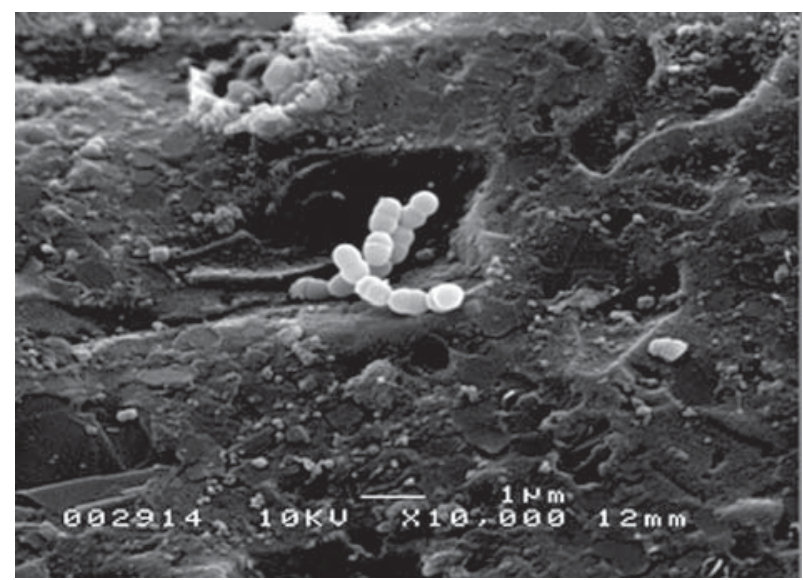

B

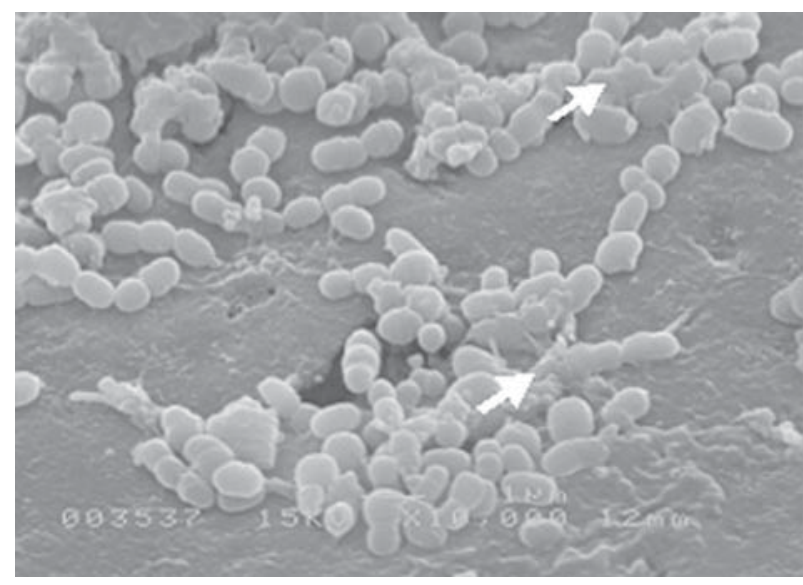

C

Figure 2- Scanning electron microscope micrographs of S. mutans cells grown on glass beads in the absence and presence of $1 \%$ sucrose. A: Blank control $(10,000 x)$. Note the absence of bacteria on the glass bead's surface. B: $S$. mutans cells grown in the absence of sucrose $(10,000 \mathrm{x})$. There were not many cells adhering to the glass surface and they appeared to be in the dividing state. C: S. mutans grown in the presence of sucrose $(1 \%)(10,000 x)$. There were many cells adhering to the glass surface. The cells appeared to be covered by thick sticky extracellular layer, giving them a fluffy appearance (arrow) to the glass surface and they are in aggregates. The extracellular surface of the cells appeared to have a layer of fluffy appearance spreading across the surface of the glass bead (Figure 2C).

The quantitative measurement of the bacterial cell population was carried out during the SEM viewing at 5,000x magnification. It was found that the number of cells adhering to the glass surface increases in the presence of sucrose and the increase was 6 -fold higher than that in the absence $(p<0.0001)$ (Table 1).

The cell surface area of the bacterial cells which was calculated based on the SEM viewing at 10,000x magnification is shown in Table 2. It was found that there was an increase (33\%) in the cell surface area of the bacterial cells when grown in the presence of sucrose compared to that grown in the absence $(p<0.0001)$.

Effect of Piper betle L. leaves on the adherence capacity and growth of $S$. mutans in the presence and absence of $1 \%$ sucrose

The SEM micrographs in Figure 3 show the effect of the different concentrations of the Piper betle $\mathrm{L}$. leaves extract on bacterial cells grown in the BHI broths without sucrose and with $1 \%$ sucrose based on the analysis at 10,000x magnification (without sucrose in the presence of $2 \mathrm{mg} \mathrm{mL}^{-1}$ extract Figure $3 \mathrm{~A}$; with $1 \%$ sucrose in the presence of 2 $\mathrm{mg} \mathrm{mL}^{-1}$ extract - Figure 3B; without sucrose in the presence of $4 \mathrm{mg} \mathrm{mL}^{-1}$ extract - Figure 3C; and with $1 \%$ sucrose in the presence of $4 \mathrm{mg} \mathrm{mL}^{-1}$ extract Figure 3D). The effect of the extract appeared to be concentration dependent where the number of cells adhering to the glass surface decreases with the increase in the concentration of the extract. It was shown that sucrose also has an effect on the growth and adherence of the bacterial cells.

Effect of the Piper betle L. leaves extract on the adherence capacity of the S. mutans

It was found that the addition of the Piper betle extract to the $\mathrm{BHI}$ broths reduces the cell population of $S$. mutans adhering to the glass surface. The reduction was observed both in the absence and presence of sucrose. The number of cells adhering to the glass surface reduced by $27 \%(p<0.0001)$ when grown without sucrose and in the presence of $2 \mathrm{mg}$ $\mathrm{mL}^{-1}$ of the extract compared to that in the absence of the extract. A similar reduction in the number of cell adhering to the glass surface was observed for those grown in the presence of sucrose. Increasing the extract concentration to $4 \mathrm{mg} \mathrm{mL}^{-1}$ resulted in a further decrease of the cell population, with a reduction of more than $80 \%$ both in the absence and presence of sucrose (Table 1 ). No bacterial cells were observed to be adhering to the glass surface when chlorhexidine was used instead of the extract. 
Effect of the Piper bet/e L. leaves extract on the growth of S. mutans with and without sucrose

The cell surface area of the bacterial cells grown in the presence of the extract, with and without sucrose based on the SEM viewing at 10,000x magnification is shown in Table 2. It was found that the bacterial cells grown in the presence of 2 $\mathrm{mg} \mathrm{mL}^{-1}$ of the extract without sucrose exhibited cell surface area that is not significantly different

Table 1- Comparison of the cell population of S. mutans ATCC 25175 adhering to the glass surface when grown on the glass beads in the presence of different concentrations of crude aqueous Piper betle L. extract (CA), without or with sucrose (1\%). (Statistical analysis; two-way ANOVA; scanning electron microscope at 5,000x)

\begin{tabular}{lcc}
\hline & Number of cells adhering to the glass beads $/ \mathbf{1 0 0} \boldsymbol{\mu m}^{\mathbf{2}}$ \\
\hline Experiments & Absence of sucrose & Presence of sucrose \\
Negative control (without the CA) & $22 \pm 2^{\mathrm{a}}$ & $140 \pm 12^{\mathrm{a}}$ \\
$2 \mathrm{mg} \mathrm{mL}^{-1} \mathrm{CA}$ & $16 \pm 4^{\mathrm{b}, \mathrm{x}, \mathrm{y}}$ & $101 \pm 11^{\mathrm{d}, \mathrm{x}, \mathrm{z}}$ \\
$4 \mathrm{mg} \mathrm{mL}^{-1} \mathrm{CA}$ & $4 \pm 1^{\mathrm{c}, \mathrm{x}, \mathrm{y}}$ & $22 \pm 2^{\mathrm{d}, \mathrm{x}, \mathrm{z}}$ \\
Positive control $(0.12 \%$ chlorhexidine) & $0 \pm 0$ & $0 \pm 0$ \\
\hline
\end{tabular}

The number of cells adhered to the glass beads was expressed as the mean \pm standard deviation from nine determinations $a-p<0.0001$ comparing number of adhering cells in the presence and absence of sucrose at $0 \mathrm{mg} / \mathrm{mL}$ of extract $b-p<0.0002$ comparing number of adhering cells in the presence of CA $2 \mathrm{mg} \mathrm{mL}^{-1}$ (without sucrose) and negative control (without sucrose)

$c-p<0.0001$ comparing number of adhering cells in the presence of CA $4 \mathrm{mg} \mathrm{mL}^{-1}$ (without sucrose) and negative control (without sucrose)

$d-p<0.0001$ comparing number of adhering cells in the presence of CA at the two concentrations (with sucrose) and negative control (with sucrose)

$x-p<0.0001$ comparing number of adhering cells in the presence of CA at the two concentrations (without sucrose) and CA (with sucrose)

$y-p<0.0001$ comparing number of adhering cells in the presence of CA at the two concentrations (without sucrose) and chlorhexidine (without sucrose)

$z-p<0.0001$ comparing number of adhering cells in the presence of CA at the two concentrations (with sucrose) and chlorhexidine (with sucrose)

Table 2- Comparison of the changes in the size of S. mutans ATCC 25175 cells when grown in different concentrations of the crude aqueous Piper betle L. extract (CA), in the absence and presence of sucrose (1\%). (Statistical analysis; two-way ANOVA; scanning electron microscope at 10,000x)

\begin{tabular}{lcc}
\hline & \multicolumn{2}{c}{ Cell surface area $\left(\boldsymbol{\mu m ^ { 2 } )}\right.$} \\
\hline Experiments & Absence of sucrose & Presence of sucrose \\
Negative control (without the CA) & $0.209 \pm 0.018^{\mathrm{a}, \mathrm{b}}$ & $0.278 \pm 0.026^{\mathrm{a}}$ \\
$2 \mathrm{mg} \mathrm{mL}^{-1} \mathrm{CA}$ & $0.216 \pm 0.016^{\mathrm{b}, \mathrm{x}}$ & $0.244 \pm 0.018^{\mathrm{d}, \mathrm{x}}$ \\
$4 \mathrm{mg} \mathrm{mL}^{-1} \mathrm{CA}$ & $0.146 \pm 0.010^{\mathrm{c}, \mathrm{y}}$ & $0.145 \pm 0.009^{\mathrm{e}, \mathrm{y}}$ \\
Positive control $(0.12 \%$ chlorhexidine) & $\mathrm{nd}$ & $\mathrm{nd}$ \\
\hline
\end{tabular}

The number of cells adhered to the glass beads $/ 100 \mu \mathrm{m}^{2}$ was expressed as the mean \pm standard deviation from nine determinations

$a-p<0.0001$ comparing number of adhering cells in the presence and absence of sucrose at $0 \mathrm{mg} / \mathrm{mL}$ of extract

$b-p<0.0002$ comparing number of adhering cells in the presence of CA $2 \mathrm{mg} \mathrm{mL}^{-1}$ (without sucrose) and negative control (without sucrose)

$c-p<0.0001$ comparing number of adhering cells in the presence of CA $4 \mathrm{mg} \mathrm{mL}^{-1}$ (without sucrose) and negative control (without sucrose)

$d-p<0.0001$ comparing number of adhering cells in the presence of CA at the two concentrations (with sucrose) and negative control (with sucrose)

$x-p<0.0001$ comparing number of adhering cells in the presence of CA at the two concentrations (without sucrose) and CA (with sucrose)

$y-p<0.0001$ comparing number of adhering cells in the presence of CA at the two concentrations (without sucrose) and chlorhexidine (without sucrose)

$z-p<0.0001$ comparing number of adhering cells in the presence of CA at the two concentrations (with sucrose) and chlorhexidine (with sucrose)

nd - not detectable 


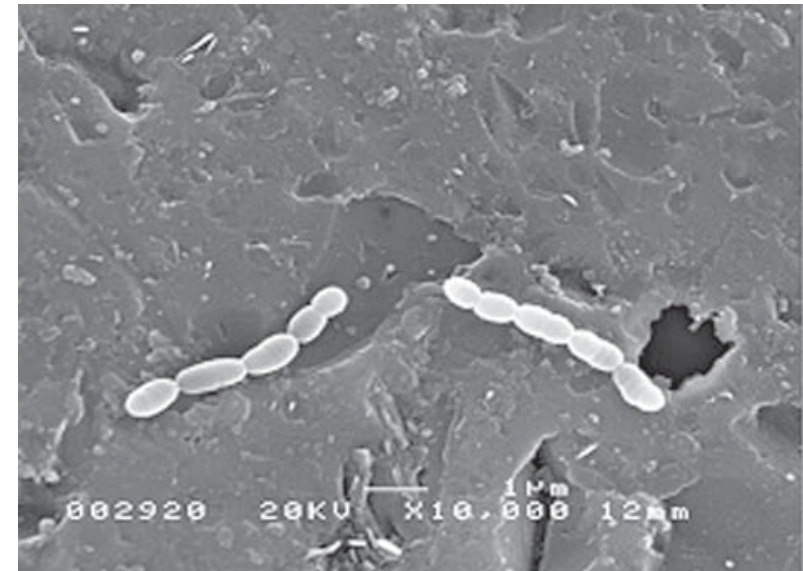

A

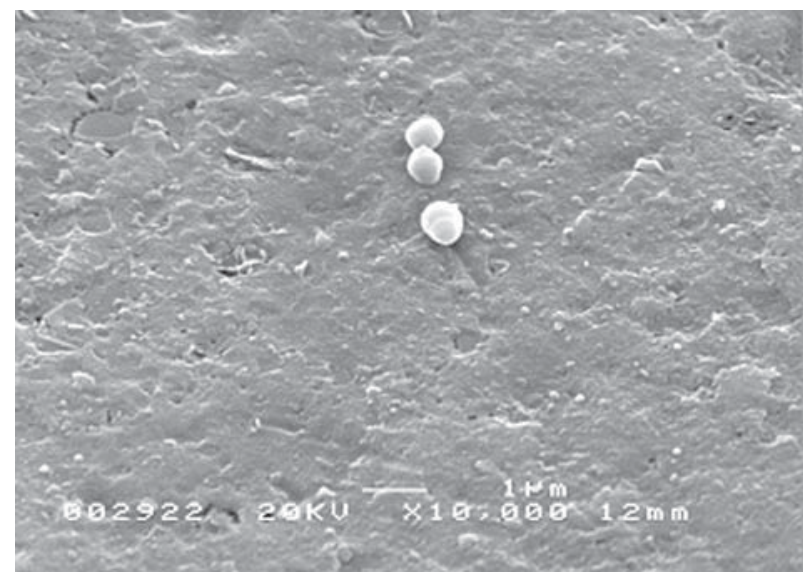

C

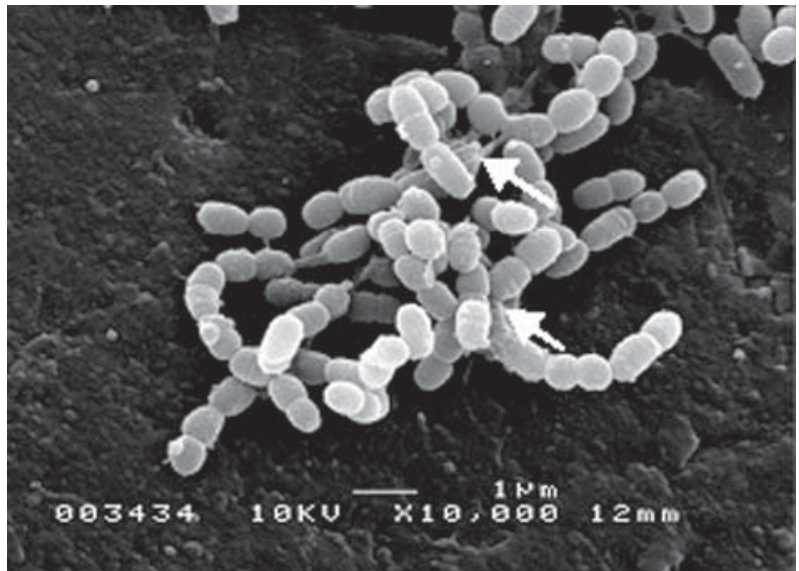

B

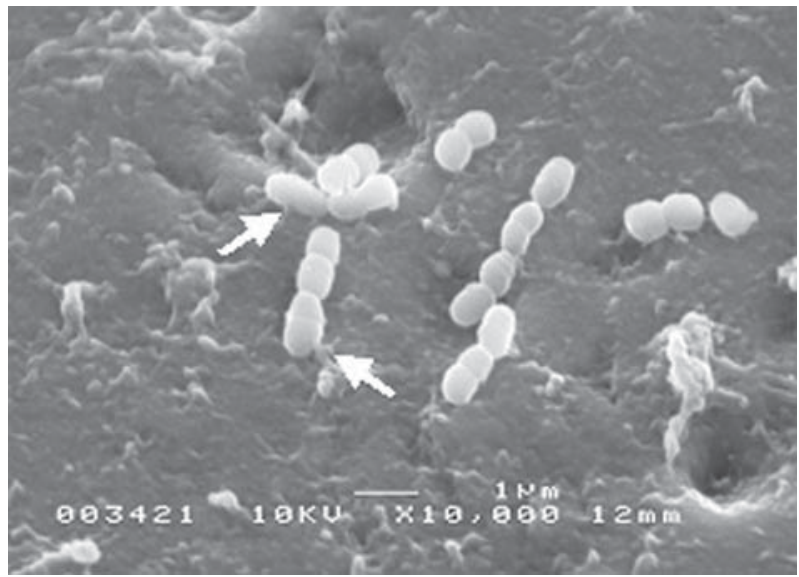

D

Figure 3- Scanning electron microscope micrographs of S. mutans cells treated with crude aqueous Piper betle L. extract (CA) on the glass beads in the absence and presence of $1 \%$ sucrose. A: S. mutans cells grown in the absence of $1 \%$ sucrose and presence of $2 \mathrm{mg} \mathrm{mL}^{-1}$ extract () viewed at 10,000x magnification. There were not many cells seen adhering to the glass surface and they appeared to be in dividing state. B: S. mutans cells were grown in the presence of $1 \%$ sucrose and $2 \mathrm{mg} \mathrm{mL}^{-1}$ extract viewed at magnification 10,000x. There were very few cells adhering to the glass surface and they appeared to be in the dividing state. Fluffy extracellular surface appearance is also observed (arrow). C: S. mutans cells grown in the absence of $1 \%$ sucrose and presence of $4 \mathrm{mg} \mathrm{mL}^{-1}$ extract viewed at magnification 10,000x. Fewer cells were seen adhering to the surface compared to that in Figure $3 \mathrm{~A}$ and they also appeared to be in dividing state. D: $S$. mutans cells grown in the presence of $1 \%$ sucrose and $4 \mathrm{mg} \mathrm{mL}^{-1}$ extract viewed at magnification 10,000x. Fewer cells were seen adhering to the surface compared to that in Figure $3 \mathrm{~B}$

from those grown in the absence of the extract. Increasing the concentration of the extract to 4 $\mathrm{mg} \mathrm{mL}^{-1}$ decreases the cell surface area by $30 \%$ $(p<0.0001)$.

It is shown in Table 2 that the cell surface area of the bacterial cells grown in the presence of $1 \%$ sucrose and $2 \mathrm{mg} \mathrm{mL}^{-1}$ of the extract is reduced by $12 \%$ compared to that of those grown without the extract $(p<0.0078)$. The bacterial cells also appeared to aggregate and exhibit fluffy extracellular surface but to a lesser extent compared to those grown in the absence of the extract (Figure 3B versus Figure $2 \mathrm{C}$ ). There was an almost $50 \%$ reduction in the cell surface area when the bacterial cells were grown in the presence of a higher extract concentration $\left(4 \mathrm{mg} \mathrm{mL}^{-1}\right)(p<0.001)$.
It was observed that the effect of the different concentrations of the extract is not greatly influenced by the presence of sucrose. The cell surface area of the bacteria in the presence of $1 \%$ sucrose and $2 \mathrm{mg} \mathrm{mL}^{-1}$ extract only increased by $12 \%$ compared to the cell surface area of those in the absence of sucrose $(p<0.0002)$. At $4 \mathrm{mg} \mathrm{mL}^{-1}$ concentration of the extract, the bacterial cells attained almost similar size both in the presence and absence of sucrose.

Effect of the Piper betle L. leaves extract on the activity of partially purified cellassociated GTF (CAG)

Table 3 shows the effect of the extract on the partially purified CAG activity. The activity 
Table 3- The effect of crude aqueous Piper betle L. extract (CA) on the activity of partially purified CAG (based on the rate of production of water insoluble glucan, determined from the glucose content). Results are expressed as the mean value \pm standard deviation of 9 determinations. $\mathrm{CHX}$ - chlorhexidine. (Statistic analysis: one-way ANOVA)

\begin{tabular}{cc}
\hline Experiments & Enzyme activity ( $\mu$ mol glucose $/ \mathrm{min}$ ) \\
\hline Negative control (without the CA) & $0.034 \pm 0.002$ \\
\hline $0.5 \mathrm{mg} \mathrm{mL}^{-1} \mathrm{CA}$ & $0.024 \pm 0.002^{\mathrm{a}, \mathrm{b}}$ \\
$1.0 \mathrm{mg} \mathrm{mL}^{-1} \mathrm{CA}$ & $0.022 \pm 0.002^{\mathrm{a}, \mathrm{b}}$ \\
$1.5 \mathrm{mg} \mathrm{mL}^{-1} \mathrm{CA}$ & $0.018 \pm 0.001^{\mathrm{a}, \mathrm{b}}$ \\
$2.0 \mathrm{mg} \mathrm{mL}^{-1} \mathrm{CA}$ & $0.014 \pm 0.001^{\mathrm{a}, \mathrm{b}}$ \\
$2.5 \mathrm{mg} \mathrm{mL}^{-1} \mathrm{CA}$ & $0.010 \pm 0.001^{\mathrm{a}, \mathrm{c}}$ \\
$4 \mathrm{mg} \mathrm{mL}^{-1} \mathrm{CA}$ & $\mathrm{nd}$ \\
\hline Positive control $(0.12 \% \mathrm{CHX})$ & $0.009 \pm 0.001^{\mathrm{a}}$ \\
\hline
\end{tabular}

a $-p<0.0001$ comparing plant extract-treated glucosyltransferase samples to negative control $b-p<0.0001$ comparing plant extract-treated glucosyltransferase samples to positive control c - $p<0.0675$ comparing CA $2.5 \mathrm{mg} \mathrm{mL}^{-1}$-treated glucosyltransferase samples to positive control nd- not detectable

was expressed as $\mu \mathrm{mol}$ glucose content of the extracellular polysaccharide per minute and was found to decrease in the presence of the extract. The inhibitory effect was found to be concentration dependent and was more significant at higher concentrations of the extract. At $0.5 \mathrm{mg} \mathrm{mL}^{-1}$ of the extract, the partially purified CAG activity was reduced by $29 \%(p<0.0001)$ when compared with the negative control (without the plant extract). At a higher concentration of the extract $\left(1 \mathrm{mg} \mathrm{mL}^{-1}\right)$, the activity was reduced by $35 \%(p<0.0001)$ and at $2.5 \mathrm{mg} \mathrm{mL}^{-1}$ of the extract, the decrease was $70 \%(p<0.0001)$, the latter being almost similar to that observed with chlorhexidine ( $p>0.05)$. Increasing the concentration of the extract to 4 $\mathrm{mg} \mathrm{mL}^{-1}$ resulted in undetectable partially purified CAG activity.

\section{DISCUSSION}

In this study, the SEM was used to determine both visually and quantitatively i) the effect of sucrose on growth and adhering property of $S$. mutans and ii) the effect of Piper betle extract on $S$. mutans in the presence and absence of sucrose. The SEM study can also be used to show the appearance of the extracellular surface of the cells in the presence of the extract with or without sucrose. Previous studies $2,8,24,30$ had employed spectrophotometric technique that allows for quantitative determination of cell population (CFU $\mathrm{mL}^{-1}$ ) to relate bacterial population and growth.

The increase in cell population adhering to glass surface in the presence of sucrose compared with those in the absence indicates that sucrose has a role in the adhering property ${ }^{30}$ and growth

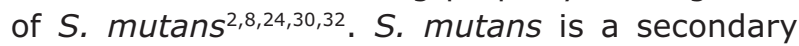

colonizer of dental plaque featuring cariogenic properties including cell adhesion, cell surface hydrophobicity and glucan synthesis activities ${ }^{21}$. The initial adherence or attachment of bacteria to the tooth surfaces may involve hydrophobic and ionic interactions between the receptors on the host surface and the adhesins on the cell surface of the bacteria ${ }^{11,12}$. The extracellular polysaccharide (glucan) which is formed favorably in the presence sucrose may be responsible in enhancing the adherence of more bacterial cells to the host surface.

The size of the bacterial cells is reflected by the cell surface area. It was found to be increased by $33 \%$ in the presence of sucrose. Sucrose is a good substrate for GTF as its hydrolysis produces energy sufficient for the polymerization of glucose in the formation of glucan, an extracellular polysaccharide. Thus its presence in the BHI broth helps to promote the activity of this enzyme. This explains for the formation of the extracellular polysaccharide which gives fluffy appearance of the extracellular surface of $S$. mutans when grown in the presence of sucrose.

For all the experiments to show the effect of the extract of Piper betle L. leaves towards $S$. mutans, sub-minimal inhibitory concentrations (sub-MICs) ( $2 \mathrm{mg} \mathrm{mL}^{-1}$ and $4 \mathrm{mg} \mathrm{mL}^{-1}$ ) were used. These concentrations were used to ensure that the observed reduced number of adhering cells was not attributed to cell death. This parameter has been used as a reference for bacteriostatic effect of plant extract ${ }^{20}$.

It was shown that the Piper betle L. leaves extract reduces adherence of the bacterial cells to the glass surface, and this is further confirmed by the calculated cell population visualized by SEM. 
It was thought that the reduced adherence is attributed to extracellular polysaccharide not being formed efficiently, which is due to reduced GTF activity in the presence of the extract.

In this study, it was shown that there are bacteria though few in number adhering to the glass surface despite the undetectable GTF activity in the presence of $4 \mathrm{mg} \mathrm{mL}^{-1}$ of the extract. In the presence of $0.12 \%$ chlorhexidine there were no bacterial cells adhering to the glass surface and at that concentration, the GTF activity corresponds to that of $2.5 \mathrm{mg} \mathrm{mL}^{-1}$ of the extract and, cell adherence was observed in the presence of the later. This suggests that GTF is not involved and that other factors such as hydrophobic and ionic interactions maybe involved in the adherence or attachment of bacteria to the tooth surfaces which, is in agreement with what had been reported in previous work ${ }^{11,12}$. However, it has been shown that the cell surface hydrophobicity of $S$. mutans is reduced in the presence of the plant extract ${ }^{16}$. The crude Piper betle L. leaves extract may have influenced the adhesion between the cell surface of the bacteria and the host surface via ionic interaction which could be responsible for the adherence effect demonstrated at $4 \mathrm{mg} \mathrm{mL}^{-1}$ extract concentration.

It was also shown that the Piper betle L. leaves extract has an influence on the cell surface area (size) of the bacterial cells. The presence of sucrose appears not to have effect on the cell surface area of bacterial cells in the presence of the $4 \mathrm{mg} \mathrm{mL}^{-1}$ extract as with or without sucrose, the bacterial cells appear to attain similar cell surface area. This indicates that bacteria grown in the presence of the extract could experience environmental stress, which could influence its ability to use nutrients efficiently and thereby slows down its growth ${ }^{5,29}$. It has been reported that the aqueous Piper betle L. extract exhibited similar effect towards other oral bacteria for example, S. sanguinis, S. mitis and Actinomyces sp. ${ }^{5}$.

\section{CONCLUSION}

The SEM analysis provided visual (qualitative) and quantitative evidence that the Piper betle L. leaves extract has a reducing effect on cell adhesion, cell growth and extracellular appearance of S. mutans. The effect of the Piper betle L. leaves extract on the GTF activity and adherence capacity of $S$. mutans suggests the involvement of other factors in the adherence of bacterial cells to the glass surface.

\section{ACKNOWLEDGEMENTS}

This project was supported by research grants (Vote $\mathrm{F}$ and IRPA) provided by the Malaysian government. The authors would like to acknowledge Ms Zubaidah Abu Hassan of the Electron Microscopy Unit, Medicine School, University of Malaya for their assistance in the electron microscopy procedure.

\section{REFERENCES}

1- Black C, Allan I, Ford SK, Wilson M, McNab R. Biofilm-specific surface properties and protein expression in oral Streptococcus sanguis. Arch Oral Biol. 2004;49:295-304.

2- Cury JA, Francisco SB, Del Bel Cury AA, Tabchoury CP. In situ study of sucrose exposure, mutans streptococci in dental plaque and dental caries. Braz Dent J. 2001;12:101-4.

3- Duarte S, Koo H, Bowen WH, Hayacibara MF, Cury JA, Ikegaki $M$, et al. Effect of a novel type of propolis and its chemical fractions on glucosyltransferases and on growth and adherence of mutans streptococci. Biol Pharm Bull. 2003;26:527-31.

4- Dubois M, Gilles K, Hamilton JK, Rebers PA, Smith F. A colorimetric method for determination of sugars and related substances. Anal Chem. 1956;28:350-6.

5- Fathilah AR, Yusoff M, Rahim ZHA. The effect of Psidium guajava and Piper betle extracts on the morphology of dental plaque bacteria. Pak J Med Sci. 2009;25:928-33.

6- Hamada S, Slade HD. Biology, immunology and cariogenicity of Streptococcus mutans. Microbiol Review. 1980;44:331-84.

7- Hannig C, Ruggeri A, Al-Khayer B, Schmitz P, Spitzmüller B, Deimling $D$, et al. Electron microscopic detection and activity of glucosyltransferase B, C and D in the in situ formed pellicle. Arch Oral Biol. 2008;53:1003-10.

8- Karjalainen S, Karjalainen M, Söderling E. Effect of sucrose rinses on the oral microflora and on salivary sucrase activity. Caries Res. 1993;27:38-42.

9- Kirtikar KR, Basu BD. Indian Medicinal Plants. Allahabad: Lalit Mohan Basu Publications; 1933. v. III, p.2128.

10- Limsong J, Benjavongkulchai E, Kuvatanasuchati J. Inhibitory effect of some herbal extracts on adherence of Streptococcus mutans. J Ethnopharmacol. 2004;92:281-9.

11- Marsh PD. Dental plaque as a microbial biofilm. Caries Res. 2004;38:204-11.

12- Marsh PD, Martin MV. Oral Microbiology. $5^{\text {th }}$ ed. Philadelphia: Churchill Livingstone; Elsevier Ltd; 2009.

13- Matsumoto M, Minami T, Sasaki H, Sobue S, Hamada S, Ooshima T. Inhibitory effects of oolong tea extract on caries inducing properties of mutans streptococci. Caries Res. 1999;33:441-5.

14- Mukasa H, Shimamura A, Tsumor H. Effect of salts on waterinsoluble glucan formation by glucosyltransferase of Streptococcus mutans. Infect Immun. 1979;23:564-70.

15- Murchison $\mathrm{H}$, Larrimore $\mathrm{S}$, Curtiss $\mathrm{R} 3^{\text {rd }}$. Isolation and characterization of Streptococcus mutans mutants defective in adherence and aggregation. Infect Immun. 1981;34:1044-55. 16- Nalina T, Rahim ZH. The crude aqueous extract of Piper betle L. and its antibacterial effect towards Streptococcus mutans. Amer J Biotech Biochem. 2007;3:10-5.

17- Nalina T, Rahim ZH. The effect of Piper betle L. leaf extract on the virulence activity of Streptococcus mutans. Pak J Biol Sci. 2006; $9: 1470-5$.

18- Ooshima T, Osaka Y, Sasaki H, Osawa K, Yasuda H, Matsumura $M$, et al. Caries inhibitory activity of cacao bean husk extract in in vitro and animal experiments. Arch Oral Biol. 2000,45:639-45. 19- Ooshima T, Yoshida T, Hamada S. Detection of caries-inducing microorganisms in hyposalivated rats without infection of mutans streptococci. Microbiol Immunol. 1994;38:39-45.

20- Prabu GR, Gnanamani A, Sadulla S. Guaijaverin - a plant flavonoid as potential antiplaque agent against Streptococcus mutans. J Appl Microbiol. 2006;101:487-95.

21- Rahim ZH, Khan HB. Comparative studies on the effect of crude aqueous (CA) and solvent (CM) extracts of clove on the cariogenic properties of Streptococcus mutans. J Oral Sci. 2006;48:117-23. 
22- Ramji N, Ramji N, Iyer R, Chandrasekharan S. Phenolic antibacterials from Piper betle in the prevention of halitosis. J Ethnopharmacol. 2002;83:149-52.

23- Razak FA, Rahim, ZH. The anti-adherence effect of Piper betle L. and Psidium guajava extracts on the adhesion of early settlers in dental plaque to saliva-coated glass surfaces. J Oral Sci. 2003;45:201-6.

24- Seppä L, Pöllänen L, Hausen H. Streptococcus mutans counts obtained by a dip-slide method in relation to caries frequency, sucrose intake and flow rate of saliva. Caries Res. 1988;22:226-9. 25- Sharma S, Khan IA, Ali I, Ali F, Kumar M, Kumar A, et al. Evaluation of the antimicrobial, antioxidant and antiinflammatory activities of hydoxychavicol for its potential use as an oral care agent. Antimicrob Agents Chemother. 2009;53:216-22.

26- Smith JR, Laudicinia RJ, Rufi RD. Learning guides for microbiology laboratory. New York: John Wiley \& Sons; 1985.

27- Song JH, Yang TC, Chang KW, Han SK, Yi HK, Jeon JG. In vitro effects of a fraction separated from Polygonum cuspidatum root on the viability, in suspension and biofilms, and biofilm formation of mutans streptococci. J Ethnopharmacol. 2007;112:419-25.
28- Staat RH, Langley SD, Doyle RJ. Streptococcus mutans adherence: presumptive evidence for protein-mediated attachment followed by glucan-dependent cellular accumulation. Infect Immun. 1980;27:675-81.

29- Tao L, Tanzer JM, MacAlister TJ. Bicarbonate and potassium regulation of the shape of Streptococcus mutans NCTC $10449 S$. J. Bacteriol. 1987;169:2543-7

30- Wan Nordini HW, Razak FA, Rahim ZH. The role of sucrose in the development of oral biofilm in a simulated mouth system. Online J. Biol Sci. 2006;6:51-5.

31- The Wealth of India. A dictionary of Indian raw materials and industrial products. New Delhi: Publications and Information Directorate, Council of Scientific and Industrial Research; 1969. v. 8.

32- Wen ZT, Baker HE, Burne RA. Influence of Brp A on critical virulence attributes of Streptococcus mutans. J Bacteriol. $2006 ; 188: 2983-92$. 